\title{
Mixed chopped and ground grass hay for dairy cows vs. grazing plus concentrates
}

\author{
Paul F. Randel
}

\begin{abstract}
A total mixed ration (TMR) containing $40 \%$ grass hay (half chopped, half finely ground) and $60 \%$ concentrates, was fed to 16 cows in groups of 4 , while 12 control cows rotationally grazed grass pasture and received individual concentrate supplemenfation, during 90 days of comparison. Mean results for control and TMR treatments were daily milk production, 14.5 vs. $15.8 \mathrm{~kg}$; milk fat percentage, 2.98 vs. 3.03 ; ratio of milk produced per concentrates consumed, 2.50 vs. 1.55 , respectively. The latter difference was significant $(P=.01)$. Daily intake of TMR was $17.0 \mathrm{~kg}$ and the ratio of milk yield/TMR intake was 0.93 . The $40 \%$ hay: $60 \%$ concentrates TMR, with half of the hay in large-particle form, represents a promising alternative feeding system, but would give more competitive efficiency of concentrate utilization if fed to cows of greater productive potential than those of the present experiment.
\end{abstract}

\section{RESUMEN}

Una ración mezclada completa incluyendo heno picado y molido comparado con pastoreo y concentrado para vacas lecheras

Una ración completa mezclada (TMR), compuesta de $40 \%$ de heno de gramíneas (la mitad picado y la otra mitad molido fino y $60 \%$ de concentrados, se le suplió a 16 vacas en grupos de 4 , mientras 12 vacas testigo apacentaron rotacióna en predios de gramíneas y recibieron suplementación individual de concentrados, durante $\mathbf{9 0}$ días de comparación. Los resultados medios obtenidos con los tratamientos testigo y TMR fueron producción de leche diaria, 14.5 contra $15.8 \mathrm{~kg}$; porcentaje de grasa láctea, 2.98 contra 3.03; proporción de leche producida por concentrados consumidos, 2.50 contra 1.55 , respectivamente. Esta última diferencia fue signifeativa $(P=.01)$. El consumo diario de TMR fue $17.0 \mathrm{~kg}$ y la proporción de leche producida por TMR ingerida fue de 0.93 . La TMR, de $40 \%$ heno: $60 \%$ concentrados, con la mitad del heno en trozos, representa un sistema alternativo de alimentación promisorio, pero daría una eficiencia en la utilización de los concentrados más competitiva si se usara con vacas de mayor pofencial productivo que las del experimento presente.

\section{INTRODUCTION}

The use of total mixed rations (TMR) for lactating dairy cows has become commonplace in many of the leading dairy countries and its adoption in commercial practice in Puerto Rico has been proposed. This system of feeding cows in confinement permits intensification of land use

'Animal Nutritionist, Department of Animal Science. 
and stricter control over the composition of the entire ration ingested than is usually possible with the traditional method of feeding forages and concentrates separately.

In a previous experiment, a comparison was made between two TMR containing $40 \%$ grass hay in either coarsely chopped or medium ground form (5). The former, but not the latter, showed evidence of supplying sufficient effective fiber to maintain normal digestive function and milk fat content. However, $40 \%$ chopped hay in the mixture causes difficulties in mechanical handling; thus it is of interest to determine whether a lower percentage of chopped material combined with the rest of the hay in ground form suffices to provide the necessary effective fiber.

The main objective of the present study was to test a TMR containing part of the hay component in finely ground form and part in coarsely chopped form, with regard to effects on milk production and milk fat percentage and feed intake and efficiency, using a control of rotational grazing and supplemental concentrates for comparative purposes.

\section{MATERIALS AND METHODS}

Twenty-eight cows, 24 Holstein and 4 Brown Swiss, were divided into 4 blocks of 7 each, so as to make those of each block as uniform as possible in milk production and stage of lactation, but without regard to breed. Three randomly selected animals per block were assigned to the control treatment ( $(\mathrm{T}-1)$, while the remaining four were housed together in one of four pens subjected to the other treatment (T-2). Thus, 12 and 16 cows were assigned to $\mathrm{T}-1$ and $\mathrm{T}-2$, respectively. Mean number of days post partum of T-1 and T-2 cows upon beginning the experiment was $62.5 \pm 23.5$ and $65.2 \pm 22.4$, respectively.

The control treatment involved rotational grazing of 12 cows in a like number of unfertilized 0.5 -ha paddocks with 2 consecutive days of grazing in each 24-day cycle. The swards consisted of a mixture of gramineous species of which star (Cynodon nlemfluensis), pajón (Dichantihium annulatum) and para (Brachiaria mutica) were the most prominent of the desirable ones. Also present were appreciable proportions of less useful grasses and some herbaceous and bushy weeds. The paddocks had been rested and pasture herbage was abundant at the start of the experiment on 15 December 1988. However, rainfall was only $31 \mathrm{~mm}$ in the remainder of said month; 38 and $14 \mathrm{~mm}$ in the full months of January and February, respectively; and zero during the first 11 days of March. Grazing conditions therefore gradually deteriorated for most of the experiment. A more serious deterioration was avoided by the use of a low stocking rate ( 2 animals/ha) and brief exposure of the swards at each grazing, followed by 22 days for vegetative recuperation. Heavy rain during the final 2 weeks of experimentation $(149 \mathrm{~mm})$ ended the drought and stimulated 
J. Agric. Univ. P.R. VOL. 77, NO. 3-4, JULY/OCTOBER, 1993195

vigorous herbage growth, but this occurred too late to have much effect on the ration of $\mathrm{T}-1$ cows.

Hours of grazing were from after the afternoon milking until the next morning milking. After the latter, $\mathrm{T}-1$ cows were confined to stanchions to receive individual concentrate supplementation (table 1). The daily allowance thereof, adjusted at monthly intervals, was equal to $1 \mathrm{~kg} / 2 \mathrm{~kg}$ of milk produced above the first $5 \mathrm{~kg}$ daily, but a minimum limit was arbitrarily set at 4.5 or $5 \mathrm{~kg}$ of supplement daily, when pasture conditions appeared to be slightly better or poorer, respectively. After having ample opportunity to consume their full supplemental allowances, $\mathrm{T}-1$ animals were kept until the afternoon milking in an unpaved yard, partially shaded by the shadows of adjacent structures, where drinking water was available.

The TMR (table 1) was not fed ad libitum, but in mean amounts per head calculated to meet the energy requirements of the 2 highest producing T-2 cows of each pen, according to National Research Council (NRC) (4). Cows had access to this ration overnight between the afternoon and the morning milkings. Orts were recovered when present and weighed daily to determine feed consumption. The pens were concrete-paved and equipped with a manger and water trough; three were located under a Saran shade and the 4th occupied one end of the shade barn. From after the morning to the afternoon milking T-2 cows rested in an unpaved enclosure with tree shade and drinking water available.

The first 11 days of experimentation were considered to constitute an adjustment period. This was followed by 90 days of comparison period, divided into three subperiods of 30 days. During each subperiod, individual aliquots of milk from two consecutive milkings were analyzed for fat

TABLE 1.-Percentages formulas of supplemental concentrates and total mixed ration and theoretical nutrient contents on a dry basis

\begin{tabular}{lcc}
\hline $\begin{array}{l}\text { Ingredient } \\
\text { or nutrient }\end{array}$ & $\begin{array}{c}\text { Supplemental } \\
\text { concentrates }\end{array}$ & $\begin{array}{c}\text { Total } \\
\text { mixed } \\
\text { ration }\end{array}$ \\
\hline Ground yellow maize & 55.3 & 29.0 \\
Wheat middlings & 32.5 & 12.2 \\
Soybean meal & 4.5 & 10.4 \\
Cane molasses & 6.0 & 6.4 \\
Salt & 0.9 & 0.8 \\
Urea & 0.4 & 0.7 \\
Dicalcium phosphate & 0.4 & 0.5 \\
Ground grass hay & - & 20.0 \\
Chopped grass hay & - & 20.0 \\
Crude protein (\%) & 13.0 & 14.0 \\
Net energy (Mcal NEL/kg) & 1.90 & 1.55 \\
\hline
\end{tabular}


content by the Babcock method (1). It was not possible to determine liveweights. Supplemental concentrates and the TMR were analyzed for contents of dry matter (DM), by oven-drying at $60^{\circ} \mathrm{C}$; ash, by incineration at $550^{\circ} \mathrm{C}$; crude protein (CP), by micro-Kjeldahl procedure.

Data on productions of milk, $4 \%$ fat-corrected milk (FCM) and milk fat; milk fat percentage; and ratios of milk produced to concentrates consumed and FCM produced to cencentrates DM consumed, were analyzed by a 2 -factor analysis of variance, appropriate to an experiment of randomized block design (6). There were three degrees of freedom for the error variance, as groups constituted the treatment replications.

\section{RESULTS AND DISCUSSION}

During the 11-day adjustment period, mean daily milk yield in T-1 was $0.7 \mathrm{~kg}$ less than in T-2 (table 2). Assigning an arbitrary index value of 100 to the mean of T-1, relative production of T-2 was 104. Withintreatment variability in daily production ranged as follows: among groups, T-1, 13.2 to $20.8 \mathrm{~kg}$; T-2, 15.1 to $21.3 \mathrm{~kg}$; among individual cows, T-1, 12.2 to $22.3 \mathrm{~kg}$; T-2, 13.5 to $25.5 \mathrm{~kg}$. During the first 30 -day comparison subperiod mean daily milk yield decreased relative to the previous period by $0.5 \mathrm{~kg}$ in both treatments. In the second subperiod the T-1 mean declined more steeply $(1.7 \mathrm{~kg})$, corresponding to a drop of 10 points in production index. A further decline of $1.3 \mathrm{~kg}$ and 8 index points was registered in the third subperiod. The mean of T-2 declined less in the second subperiod $(0.7 \mathrm{~kg})$, but subsequently also showed a steep decrease of $1.7 \mathrm{~kg}$, corresponding to 10 index points, in the third subperiod. The $1.3 \mathrm{~kg}$ difference between treatments in daily milk yield during the full 90 days was not significant $(P=.10)$. The 7-point between-treatment difference in production index during the comparison period was only 3 points above that of the adjustment period.

Variability among the four groups of $\mathrm{T}-2$ was lower than that among those of $\mathrm{T}-1$ throughout the experiment, more so in the comparison

TABLE 2.-Mean daily milk production $(\mathrm{kg})$ and corresponding standard deviation and production index (P. I.)

\begin{tabular}{ccccccc} 
& & \multicolumn{2}{c}{ Control } & & \multicolumn{2}{c}{ Total mixed ration } \\
\cline { 6 - 7 } Period & Days & Production & P.I. & & Production & P.I. \\
\hline Adjustment & 11 & $16.6 \pm 3.3$ & 100 & & $17.3 \pm 2.8$ & 104 \\
Comparison & & & & & \\
1 & 30 & $16.1 \pm 4.3$ & 97 & & $16.8 \pm 2.8$ & 101 \\
2 & 30 & $14.4 \pm 3.8$ & 87 & & $16.1 \pm 2.7$ & 97 \\
3 & 30 & $13.1 \pm 3.1$ & 79 & & $14.4 \pm 1.9$ & 87 \\
Total & 90 & $14.5 \pm 3.7$ & 88 & & $15.8 \pm 2.5$ & 95 \\
\hline
\end{tabular}


period. The initially higher producing groups of T-2 decreased more than those of lower initial productivity (within-treatment regression of comparison period production on adjustment period production $b=0.86$ vs. $\mathrm{b}=1.06$ for T-1). This might have been a consequence of the different feeding procedures, with the higher producing cows benefiting from individual concentrate supplementation in $\mathrm{T}-1$, but not from group feeding of restricted amounts of TMR in T-2.

Milk fat content in T-1 showed a slight increase with time; mean percentages, weighed according to milk and fat productions of individual cows, were $2.84,2.91$ and 2.97 in successive subperiods of comparison. In T-2 this upward trend was irregular; corresponding means of 2.97 , 2.85 and 3.23 were observed. Over-all weighted means favored T-2 by $0.11 \%$ ( 2.90 vs. 3.01 ). Unweighted means differed between treatments by only $0.05 \%$ (table 3 ). Only the latter could be tested statistically and the difference in question did not approach significance. Mean daily production of milk fat favored $\mathrm{T}-2$ by $0.05 \mathrm{~kg}$, but this difference was $\mathrm{P}=$ .10. Daily FCM yield was also higher for the groups fed the TMR than for the control cows by the same margin of $1.3 \mathrm{~kg}(P=.10)$ as in the case of milk production, within the limits of rounded numbers.

Daily consumption of concentrate DM by the cows that grazed was less than that of concentrates contained in the TMR (60\% of the formula) by a margin of $3.9 \mathrm{~kg}$ (table 3). Control cows ingested $57 \%$ as much concentrate DM as those of T-2. Mean analytical values determined for supplemental concentrates and TMR on a dry basis were CP, $15.5 \%$ and $14.1 \%$; ash, $4.4 \%$ and $8.8 \%$, respectively. One important criterion of feed efficiency in economic terms is the ratio of milk production per concen-

TABLE 3.-Mean daily inlake of dry matter from concentrales and tolal mixed ration, milk fat percentage, daily yields of milk fal and of $4 \%$ fat-corrected milk (FCM), and several ratios of feed conversion

\begin{tabular}{lccc}
\hline & & \multicolumn{2}{c}{ Treatment } \\
\cline { 3 - 4 } Criterion & & & $\begin{array}{c}\text { Total } \\
\text { mixed }\end{array}$ \\
\hline ration
\end{tabular}

a, Difference between treatments $(P=.01)$. 
trate consumption. The control resulted in a markedly higher ratio $(\mathrm{P}=$ .005 ) than T-2 (2.50 vs. 1.55). This benefit of efficient concentrate utilization obtained from gxazing is well documented by previous work in regions of Puerto Rico with more favorable rainfall distribution than that of Lajas (9).

Since pasture herbage consumption by the control cows is unknown, data on intake of all feed are available only for T-2, wherein $17.0 \mathrm{~kg}$ of TMR were consumed daily, equivalent to $15.1 \mathrm{~kg}$ of DM (table 3). The present findings confirm previous observations (5) on the ease of obtaining high levels of intake by offering confined cows a TMR only during the cooler hours of the diurnal cycle interval between afternoon and morning milkings. Most of the ingestive activity took place during the first hours after the cows arrived back in their pens to find feed in the manger. These results are consistent with the conclusion of Erdman et al. (2) that dairy cows in confinement require no more than 8 hours of daily access to their ration for maximum intake. The high ingestive levels obtainable with this procedure would be especially useful for feeding cows of higher productive potential than those of the present experiment.

TMR containing chopped hay in the proportions $40 \%$ (previous experiment; 5) and $20 \%$ (present study), resulted in mean milk fat percentages of 3.00 and 3.03 , respectively. This might mean that $20 \%$ of chopped hay is adequate in this type of ration and a higher proportion is of no added benefit. Finely ground ( $3.175 \mathrm{~mm}$ screen) hay, which constituted $20 \%$ of the present TMR is convenient for mechanical handling, but would not be expected to contribute to the physical action of large particle-size fiber in the rumen (sometimes referred to as scratch factor). However, the multiple regression equation developed by Sudweeks et al. (7) to estimate roughage value index includes neutral detergent fiber (NDF) content and DM intake (negative term) in addition to particle size. The fineness of grind used with the hay in the present experiment was less than that used in preparing samples ( $1 \mathrm{~mm}$ screen) for NDF determination (3); thus the contribution of this analytical fraction would be unaffected. Finely ground hay might be of value in the ration to help maintain normal intraruminal conditions by virtue of its buffering, ion exchange and possibly hydration capacities (8). When it becomes necessary to increase the net energy value of the ration, the replacement of ground hay by ingredients rich in rapidly fermentable carbohydrate would result in a greater challenge to the remaining buffering capacity of the rumen. Inclusion of ground hay of higher nutritive value might be a more advantageous alternative.

The present result led support to a previous suggestion (5) that a promising alternative for intensified dairying in Puerto Rico is a TMR composed of $40 \%$ grass hay, a sufficient proportion of which is in largeparticle form, and $60 \%$ concentrates. 


\section{LITERATURE CITED}

1. AOAC, 1980. Official Methods of Analysis. 13th ed. Association of Official Analytical Chemists. Washington, D.C.

2. Erdman, K. A., T. W. Moreland and W. R. Strickling, 1989. Effect of time of feed access on intake and production in lactating dairy cows J. Dairy Sci. 72: 1211-6.

3. Goering, H. K. and R. J. Van Soest, 1970. Forage Fiber Analysis. Agricultural Handbook No. 379, Agricultural Research Center, 7 USDA, Washington, D.C.

4. National Research Council, 1978. Nutrient Requirements of Dairy Cattle. 5th ed., National Academy of Science, Washington, D.C.

5. Randel, P. F, , 1991. Complete rations containing coarsely chopped or ground hay for dairy cows in confinement vs. conventional grazing. J. Agric. Univ. P.R. 75: 241-52.

6. Snedecor, G. W., 1956. Statistical Methods. 5th ed., The Iowa State College Press, Ames, Iowa.

7. Sudweeks, E. M., L. O. Ely, D. R. Mertens and L. R. Sisk, 1981. Assessing minimum amounts and form of roughage in ruminant diets: roughage value index system. $J$. Anim. Sci. 53: 1406-11.

8. Van Soest, P. J., 1982. Nutritional Ecology of the Ruminant. O + B Books, Inc., Corvallis, Oregon.

9. Yazman, J. A., R. E. McDowell, H. Cestero, J. A. Arroyo-Aguilú, J. D. Rivera Anaya, M. Soldevila and F. Róman-García, 1982. Efficiency of utilization of tropical grass pastures by lactating cows with and without supplement. J. Agric. Univ. P.R. 66: 200-22. 